\title{
CASCADE ENERGY TRANSFER IN INSULIN AMYLOID FIBRILS DOPED BY THIOFLAVIN T, BENZANTHRONE AND SQUARINE DYES
}

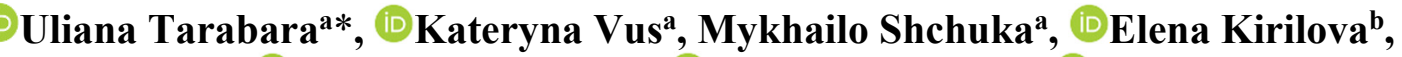

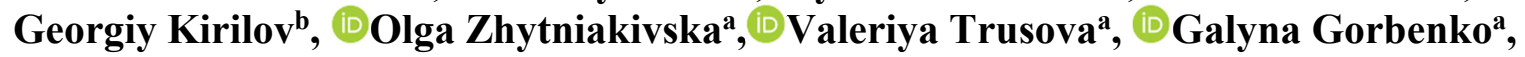 \\ Todor Deligeorgiev ${ }^{\mathbf{c}}$ \\ ${ }^{a}$ Department of Medical Physics and Biomedical Nanotechnologies, V.N. Karazin Kharkiv National University \\ 4 Svobody Sq., Kharkiv, 61022, Ukraine \\ ${ }^{b}$ Department of Chemistry and Geography, Daugavpils University, Vienibas 13, Daugavpils, LV5401, Latvia \\ "Faculty of Chemistry and Pharmacy, Sofia University, "St. Kliment Ohridski" 1, \\ blv. J. Bourchier, Sofia, 1164, Bulgaria \\ *Corresponding Author: uliana.tarabara@gmail.com \\ Received 15 January 2020, revised January 30, 2020; accepted January 31, 2020
}

\begin{abstract}
The three-step Förster resonance energy transfer (FRET) within the cascade of four dyes, including the classical amyloid marker Thioflavin T as a primary donor, two jumper dyes, benzanthrone ABM and squaraine SQ4, and terminal acceptor SQ1, was tested as a possible tool for detection and characterization of insulin amyloid fibrils. The results obtained confirm the occurrence of highly efficient multistep FRET (msFRET) in the chromophore ensemble in the presence of insulin fibrils formed at elevated temperature under $\mathrm{pH} 2$ (InsF1) or $\mathrm{pH} 7.4,0.15 \mathrm{M} \mathrm{NaCl}$ (InsF2), while negligible FRET efficiencies were obtained for the control unfibrillized protein, suggesting the specificity of msFRET to cross- $\beta$-sheet architecture characteristic of amyloid fibrils. Specifically, the efficiencies of FRET for the donor-acceptor pairs ThT-ABM, ABM-SQ4 and SQ4-SQ1 at maximum acceptor concentrations $(\sim 0.4$ $\mu \mathrm{M}-1.6 \mu \mathrm{M}$ ) were estimated to be $86 \% / 94 \%, 48 \% / 34 \%$ and $66 \% / 32 \%$, respectively, in the presence of InsF $1 /$ InsF2. The most significant differences between InsF1/InsF2 and the control protein were observed for the donor-acceptor pair ThT-ABM, suggesting that ABM is the key mediator in the whole process of msFRET. Assuming the isotropic rotation of the fluorophores, the average donor-acceptor distances were estimated in the presence of InsF1, yielding the values $1.3 \mathrm{~nm}, 5.3 \mathrm{~nm}$, and $3.9 \mathrm{~nm}$ for the ThT-ABM, ABM-SQ4 and SQ4-SQ1 pairs, respectively. The obtained distances are indicative of different fibril binding sites for the chromophores in the insulin fibrils, although due to their high specificity to the fibrillar structure, the dyes are most likely to localize in the surface grooves of $\beta$-sheets running along the main axis of amyloid fibril. Remarkably, the differences in the insulin amyloid morphology can be clearly distinguished using msFRET. As evidenced from TEM, InsF2 were thinner, shorter and contained amorphous aggregates, as compared to InsF1. Thus, different amyloid formation pathways under neutral and acidic $\mathrm{pH}$ resulted in the changes in the dye affinity for to the fibril binding sites, and, as a consequence, in the distinct msFRET efficiencies, especially for the pair SQ4-SQ1. The ability of ThT to serve as an efficient amplifier for the two near-infrared dyes, SQ4 and SQ1, with the benzanthrone fluorophore ABM as a jumper dye, allows detection of fibrillar insulin in the optical window of the biological samples, with the Stokes shift of the four-chromophore being $c a .240 \mathrm{~nm}$. The proposed msFRET-based approach can be employed not only for insulin amyloid detection but also for distinguishing between different amyloid fibril morphologies and gaining further insights into the mechanisms involved in the development of the injection-localized insulin amyloidosis.
\end{abstract}

KEYWORDS: ABM, cascade resonance energy transfer, insulin amyloid fibrils, quantum yield, Thioflavin T.

Förster resonance energy transfer (FRET) is known as a physical process by which an excited state fluorophore (donor) non-radiatively transfers energy to another fluorophore via distance-dependent long-range dipole-dipole interactions [1]. Due to this feature, FRET technique has proven to be highly informative in the structural characterization of a wide variety of biological macromolecules and their assemblies [1-4]. The efficiency of FRET depends on the distance between the chromophores employed as energy donor and acceptor, orientation of the donor and acceptor transition dipoles, and the donor quantum yield [1,5]. Numerous studies indicate that the maximum FRET efficiency can be achieved via multiple interacting FRET pathways rather than independent channels, by which the energy travels from an initial donor chromophore through the intermediate donors/acceptors onto a final acceptor chromophore [6,7]. Therefore, during the past decades the multistep FRET (msFRET), manifesting itself in the energy transfer within multiple chromophore systems through cascade route, attracts increasing attention $[8,9]$. To exemplify, the msFRET was applied for protein labeling [10], simultaneous enzyme detection in multicomponent biological samples [9], genotyping of single nucleotide polymorphism [11], DNA sequencing [12], estimating the stoichiometry of protein complexes [13], determination of the tumor necrosis factor [14] and analysis of multiprotein interactions in living cells [15], screening of multiple enzyme inhibitors [7], developing the light harvesting systems and molecular photonic wires $[6,7,16,17]$. The vast majority of the above implementations of msFRET are based on the application of DNA as a framework for arraying multiple fluorophores at precise positions and controlling the inter-chromophore distances in such a way that the energy transfer occurs on the nanoscale $[6,7,11,12,17]$.

Recently we have found that amyloid fibrils can also serve as a molecular scaffold for controlled positioning of a multitude of chromophores communicating via the two-step FRET [18,19]. Moreover, we have demonstrated that the technique based on the msFRET can be effectively used for the identification and characterization of insulin amyloid fibrils along with classical Thioflavin T (ThT) assay, thus allowing the increase of amyloid detection sensitivity [19,20]. 
For further investigation of the ability of amyloid fibrils to act as a molecular framework for arraying multiple fluorophores, herein we directed our efforts to the identification of a set of fluorophores capable of reinforcing the amyloid-sensing potential of the classical amyloid marker ThT. More specifically, the aim of the present study was to examine the applicability of the chromophore system, containing Thioflavin T, benzanthrone dye ABM, and two squaraine compounds, SQ1 and SQ4, to detecting and characterizing the insulin amyloid fibrils of different morphology.

\section{EXPERIMENTAL SECTION}

Materials

Bovine insulin, dimethyl sulfoxide (DMSO), Tris, Thioflavin T (ThT) were purchased from Sigma. Benzanthrone dye ABM [21], and squaraine dyes, SQ1, SQ4 [19], were synthesized in the Daugavpils University and University of Sofia, respectively. All other reagents were used without further purification.

\section{Preparation of working solutions}

The insulin stock solutions $10 \mathrm{mg} / \mathrm{ml}(\mathrm{InsF} 1)$ or $0.3 \mathrm{mg} / \mathrm{ml}(\mathrm{InsF} 2)$ were prepared in $10 \mathrm{mM}$ glycine buffer ( $\mathrm{pH}$ $2.0)$ or in $10 \mathrm{mM}$ Tris- $\mathrm{HCl}$ buffer $(0.15 \mathrm{M} \mathrm{NaCl})$, respectively. The reaction of the protein (stock solutions) fibrillization was conducted at $37{ }^{\circ} \mathrm{C}$ for 5 days (InsF2) and for 10 hours, followed by incubation at $55^{\circ} \mathrm{C}$ for 8 hours (InsF2) under constant agitation on the orbital shaker (108 and 143 r.p.m. for InsF1 and InsF2, respectively). The kinetics of amyloid formation was monitored using the Thioflavin $\mathrm{T}$ assay [22], revealing the dye fluorescence intensity increase at $480 \mathrm{~nm} c a .142$ and 591 times for InsF1 and InsF2, respectively (data not shown). Hereafter, the fibrillar protein and its non-fibrillized counterpart (the insulin solution in glycine or Tris-HCl buffers that was not subjected to heating and agitation) are denoted as InsF1/InsF2 and InsN1, respectively, where indexes 1 and 2 correspond to glycine and TRIS buffers, respectively.

The dyes stock solutions were prepared in DMSO (SQ1 and SQ4) and ethanol (ABM), while ThT was dissolved in $10 \mathrm{mM}$ Tris buffer (pH 7.4). The fluorimetric measurements were carried out in $10 \mathrm{mM}$ Tris- $\mathrm{HCl}$ buffer (pH 7.4).

Insulin fibril samples for transmission microscopy were contrasted by $1.5 \%(\mathrm{w} / \mathrm{v})$ phosphotungstic acid, dried and viewed with the EM-125 electron microscope (Selmi, Ukraine), as described previously [19].

A
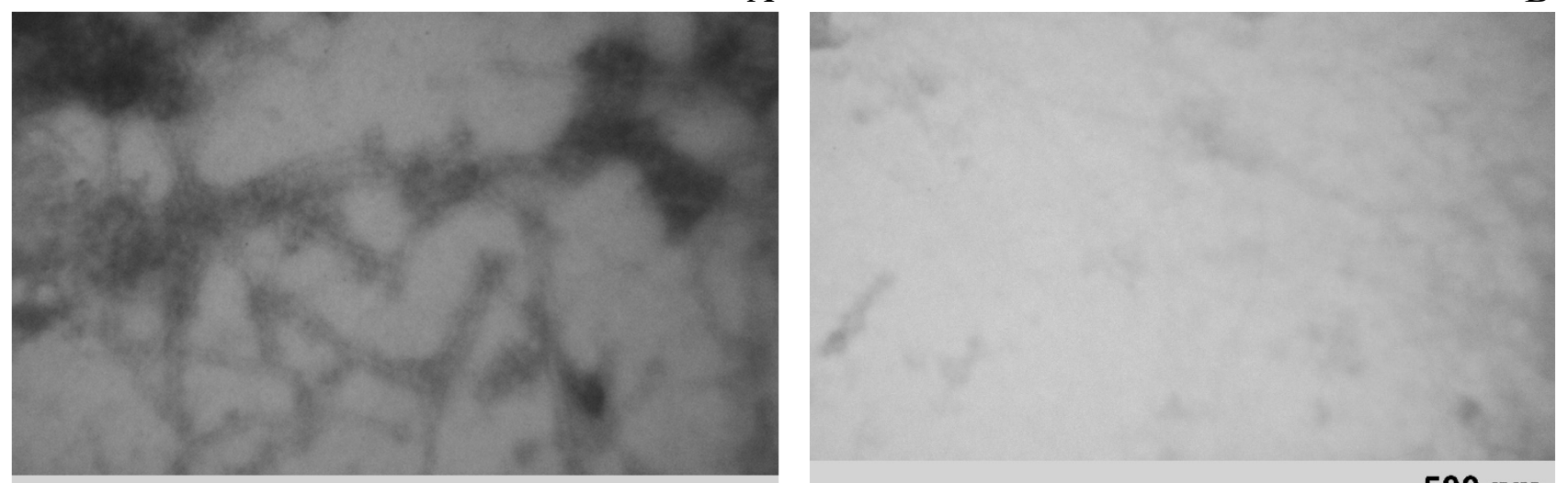

$500 \mathrm{~nm}$

Fig. 1. Transmission electron microscopy photographs of the insulin amyloid fibrils prepared in $10 \mathrm{mM}$ glycine buffer ( $\mathrm{pH} 2)(\mathrm{A}) 10$ mM Tris-HCl buffer (0.15 M NaCl, pH 7.4) (B).

\section{Spectroscopic measurements}

The absorption spectra of the examined dyes were recorded with the spectrophotometer Shimadzu UV-2600 (Japan) at $25{ }^{\circ} \mathrm{C}$. The dye concentrations were determined spectrophotometrically using the extinction coefficients $\varepsilon_{444}^{E O H}=9.3 \cdot 10^{3} \mathrm{M}^{-1} \mathrm{~cm}^{-1}, \quad \varepsilon_{662}^{\text {DMSO }}=2.3 \cdot 10^{5} \mathrm{M}^{-1} \mathrm{~cm}^{-1}, \quad \varepsilon_{641}^{\text {DMSO }}=4.21 \cdot 10^{5} \mathrm{M}^{-1} \mathrm{~cm}^{-1}$ and $\varepsilon_{412}^{\text {water }}=3.6 \cdot 10^{4} \mathrm{M}^{-1} \mathrm{~cm}^{-1}$ for ABM, SQ1, SQ4 and ThT, respectively. Steady-state fluorescence spectra were recorded with RF-6000 spectrofluorimeter (Shimadzu, Japan). Fluorescence measurements were performed at $25{ }^{\circ} \mathrm{C}$ using $10 \mathrm{~mm}$ pathlength quartz cuvettes. Fluorescence spectra were recorded within the range 460-800 nm with the excitation wavelength $440 \mathrm{~nm}$. The excitation and emission slit widths were set at $10 \mathrm{~nm}$.

The efficiency of energy transfer was determined from the quenching of the donor fluorescence in the presence of acceptor using the theory described in our previous paper [19]. Briefly, the following formulas were used [1]:

$$
E=1-\frac{I_{D A}}{I_{D}}
$$


where $I_{D}$ and $I_{D A}$, are fluorescence intensities of the free donor and in presence of the acceptor, respectively. The donor fluorescence recorded upon addition of the acceptor was corrected for inner filter effect [19]. The Förster radius was calculated using the Mathcad 15.0 software and the equations:

$$
R_{0}=979\left(\kappa^{2} n_{r}^{-4} Q_{D} J\right)^{1 / 6}, J=\int_{0}^{\infty} F_{D}(\lambda) \varepsilon_{A}(\lambda) \lambda^{4} d \lambda / \int_{0}^{\infty} F_{D}(\lambda) d \lambda
$$

where $J$ is the overlap integral; $F_{D}(\lambda)$ is the donor fluorescence intensity, $\varepsilon_{A}(\lambda)$ is the acceptor molar absorbance at the wavelength $\lambda, n_{r}$ is the refractive index of the medium; $Q_{D}$ is the donor quantum yield; $\kappa^{2}$ is the orientation factor [19]. Finally, quantum yield of the dyes was estimated from the equation:

$$
Q_{d}=Q_{s} \cdot \frac{\left(1-10^{A_{s}}\right) S_{d} n_{d}^{2}}{\left(1-10^{A_{d}}\right) S_{s} n_{s}^{2}}
$$

where $Q_{s}$ is the quantum yield of the standard, $A_{d}$ and $A_{s}$ are the absorbances at the donor excitation wavelength, $S_{d}$ and $S_{s}$ are the areas under the fluorescence curve, $n_{d}$ and $n_{s}$ are the refractive indexes of the solutions in which fluorescence spectra of the donor and standard are measured, respectively.

\section{RESULTS AND DISCUSSION}

The three-step sequential FRET was observed in the system of four dyes including the ThT (donor), ABM (the main mediator), squaraine dyes SQ4 (acceptor for ABM) and SQ1 (acceptor for SQ4) in the presence of fibrillar insulin and control unfibrillized protein (Fig. 2). A sequential chromophore addition to InsF1 and to the control unfibrillized protein, starting from the terminal acceptor (SQ1) and ending by the primary donor (ThT), resulted in the following SQ1 fluorescence intensity increases at $680 \mathrm{~nm}$ : SQ1+SQ4 ( 2), +ABM ( 20), +ThT ( 100) for InsF1 and SQ1+SQ4 $(\sim 1.2),+\mathrm{ABM}(\sim 14),+\mathrm{ThT}(\sim 15)$ for the control protein (Fig. 3A,B). Notably, increase in the fluorescence intensity of the terminal acceptor SQ1 ( $\sim 100$ for InsF1) in the presence of ABM in the four-chromophore system was higher than that in the case of 4-dimethylaminochalcone (DMC) [19], suggesting that the examined benzanthrone dye is better enhancer of SQ1 fluorescence in the msFRET occurring in the insulin amyloid fibrils. As illustrated in Fig. 3C, titration of the fibril-bound ThT with ABM is accompanied by the decrease in ThT fluorescence intensity at $480 \mathrm{~nm}$, allowing the calculation of FRET efficiency. The sample containing InsF1, ThT and ABM was then titrated with SQ4, followed by the titration with SQ1 (data not shown), and FRET efficiencies within the pairs ABM-SQ4 and SQ4-SQ1 were determined. Similar approach was employed to determine the msFRET efficiencies for the donor-acceptor pairs bound to InsF2.

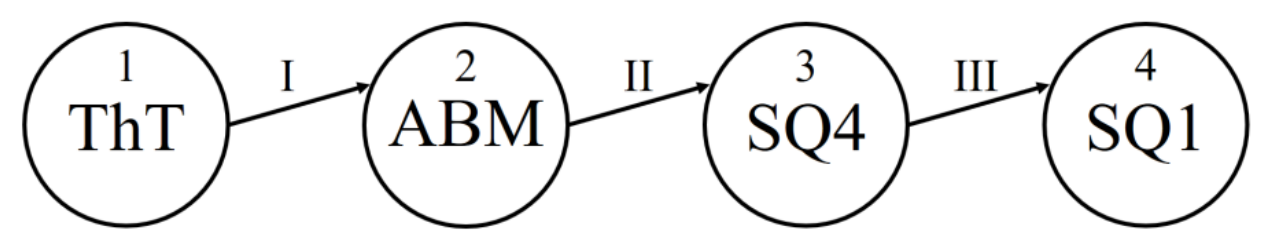

Fig. 2. Scheme of a three-step sequential energy transfer between 4 chromophores.

Interestingly, addition the dyes in the following order: SQ1, SQ4, ABM $(0.3 \mu \mathrm{M})$, ABM $(1.6 \mu \mathrm{M})$ to the InsF2ThT system, resulted in the increase of SQ1 fluorescence at $680 \mathrm{~nm}$ by $\sim 4, \sim 8, \sim 18, \sim 75$ times, respectively (Fig. 3D). These data indicate that ABM acts as a jumper dye in the FRET between ThT and SQ4, since the squaraine fluorescence intensity increases with increasing the ABM concentration (Fig. 3D). Furthermore, final increase in SQ1 fluorescence at $680 \mathrm{~nm}$ was about 100 (18) times for InsF1 (InsF2) at the SQ1, SQ4 and ABM concentrations, 0.46, 0.25 , and $0.3 \mu \mathrm{M}$, respectively. The differences observed between InsF1 and InsF2 suggest the sensitivity of msFRET to amyloid fibril morphology (Fig.3A,D). The donor quantum yields $\left(Q_{d}\right)$ presented in Table 1 were calculated using eq. (3). Notably, the ThT quantum yield was increased two orders of magnitude upon the dye binding to fibrillar insulin, that is in a good agreement with our previous data [19].

The FRET efficiencies $(E)$ evaluated for the donor-acceptor pairs ThT-ABM, ABM-SQ4 and SQ4-SQ1 at the maximum acceptor concentrations (InsF1: $0.8 \mu \mathrm{M}, 0.4 \mu \mathrm{M}$ and $1.2 \mu \mathrm{M}$; InsF2: 1.6, 0.3 and 0.4 $\mu \mathrm{M}$ for ABM, SQ4 and SQ1, respectively) are given in Table 2. Similar to our previous study with DMC [19], the energy transfer efficiencies for all donor-acceptor pairs in the cascade were higher in the presence of fibrillar insulin, as compared to the control unfibrillized protein, suggesting the specificity of msFRET for amyloid state of polypeptide chain. 
A

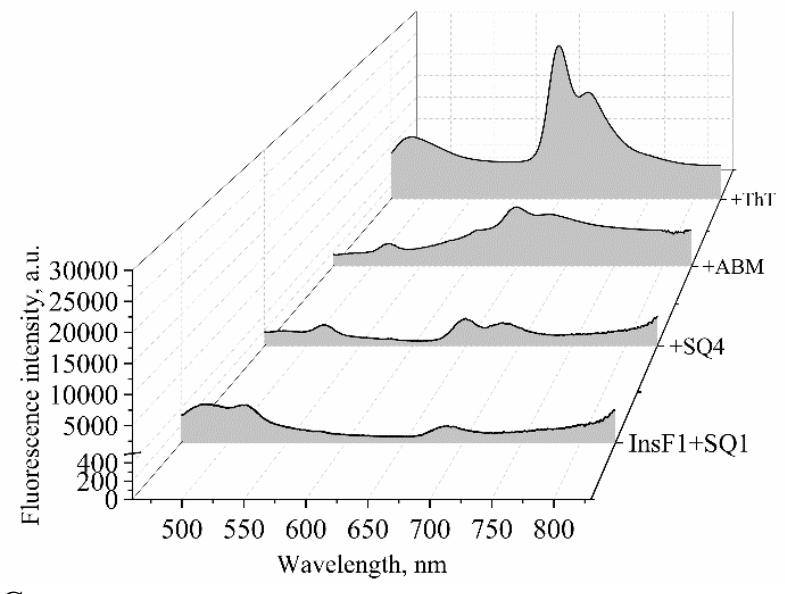

$\mathrm{C}$

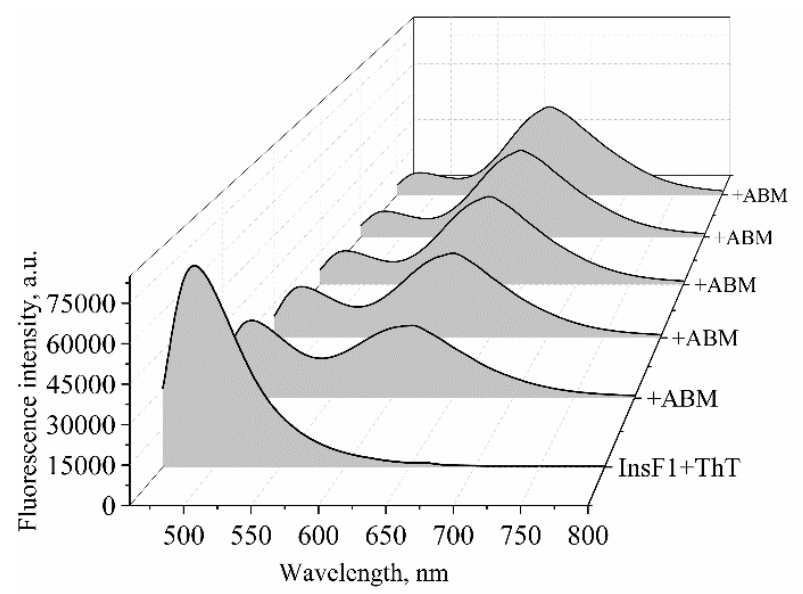

B

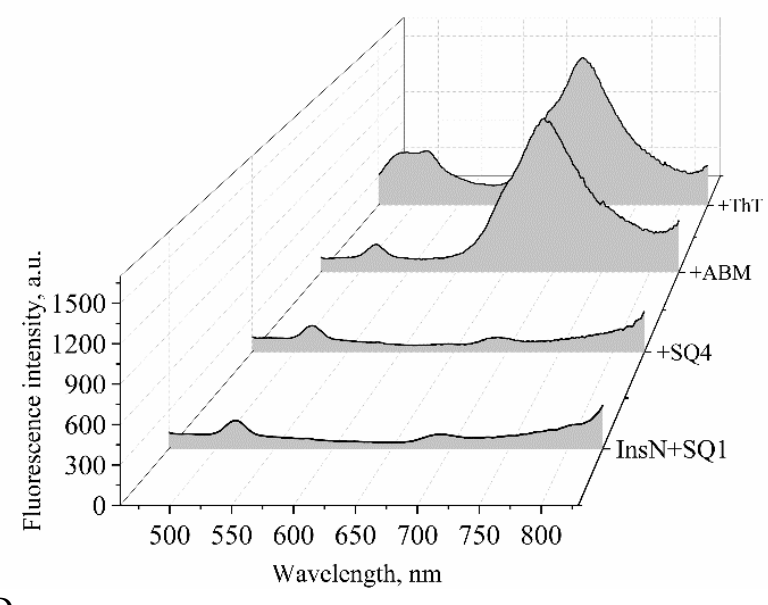

D

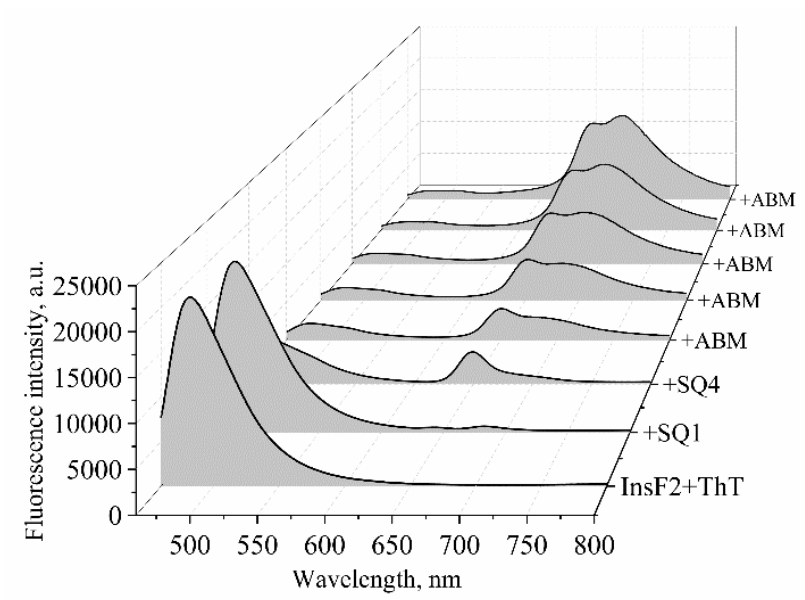

Fig. 3. Changes in the emission spectra of the squaraines (SQ1 and SQ4) upon addition of donors (ThT and ABM) in the presence of the fibrillar insulin InsF1 (A) and control protein (B). Fluorescence spectra of fibril-bound ThT upon titration with the main mediator ABM (C) or SQ1, SQ4, ABM (D). The protein and ThT concentrations were 5.6 and $3.6 \mu \mathrm{M}(\mathrm{A}-\mathrm{C}), 1.8$ and $0.16 \mu \mathrm{M}(\mathrm{D})$, respectively. SQ1 and SQ4 concentrations were 0.46 and $0.25 \mu \mathrm{M}$, respectively. $\mathrm{ABM}$ concentration was $0.3 \mu \mathrm{M}(\mathrm{A}, \mathrm{B})$, and was varied from 0.2 to $0.8 \mu \mathrm{M}(\mathrm{C})$ and from 0.3 to $1.6 \mu \mathrm{M}(\mathrm{D})$. The samples were incubated for 3-16 minutes after addition of each aliquot of the dye stock solutions to the InsF2-ThT mixture (D).

Notably, the benzanthrone dye ABM is the key mediator in a whole msFRET process, because the energy transfer efficiency for the pair ThT-ABM was the highest (Table 2). ABM appeared to be a better mediator than DMC, because only $\sim 60 \%$ FRET efficiency was observed for ThT-DMC pair in the presence of insulin amyloid fibrils [19].

Notably, FRET efficiency for the pair Q4-SQ1 was 2-fold lower in InsF2, as compared to that in InsF1 (Table 2). Furthermore, only 4\% FRET efficiency was observed for this donor-acceptor pair immediately after the addition of SQ1 to the ThT-ABM-SQ4-InsF2 system, and it reached the value of 32\% only after 19 hours of sample incubation at room temperature (Table 2), probably because of steric restrictions for the binding of bulky SQ1 molecule to InsF2. The distinct FRET efficiencies in the ensemble of four dyes in the presence of InsF1 and InsF2 can be explained by variations in fibril morphology resulting from different $\mathrm{pH}$, concentration, and ionic strengths [26]. As seen in Fig. 1A, the mature fibrils of $1.0 \pm 0.2 \mu \mathrm{m}$ in length and $30 \pm 6 \mathrm{~nm}$ in diameter were formed under acidic $\mathrm{pH}$ in the absence of $\mathrm{NaCl}$ [27]. Instead, shorter $(0.9 \pm 0.7 \mu \mathrm{m})$, thinner $(24 \pm 6 \mathrm{~nm})$ and blurred aggregates were observed upon insulin incubation at physiological $\mathrm{pH}$ (7.4) and ionic strength $150 \mathrm{mM}$ (Fig. 1B). In fact, InsF2 fibrils seem to be immature, e.g., broken fibrils or protofilaments, resulting in the different appearance of InsF1 and InsF2 structures (Fig. 1) [28]. Thus, a more pronounced loss of insulin tertiary structure induced by acidic $\mathrm{pH}$ provides fast and complete maturation (InsF1, Fig. 1A), while some amount of amorphous aggregates are formed at $\mathrm{pH} 7.4$ presumably due to screening of the electrostatic repulsion between the protein molecules (InsF2, data not shown). The latter is in good agreement with the results of Yoshihara and co-workers, who reported common amyloid structural properties of insulin fibrils formed at $\mathrm{pH}$ 1.6, $0.1 \mathrm{M} \mathrm{NaCl}$, such as high beta-sheet content and exposed C-terminal and $\mathrm{N}$-terminal parts of the B-chain [28]. In turn, the aggregates prepared at $\mathrm{pH} 7.4,0.14 \mathrm{M} \mathrm{NaCl}$ were featured by the presence of unordered structures and exposed only the C- terminal part of the B-chain. Remarkably, both electrostatic and hydrophobic intermolecular 
interactions govern insulin amyloid fibril assembly, and thus, at low $\mathrm{pH}$ insulin molecules exist as monomers, which may form amyloid nuclei.

Table 1

Donor quantum yields in the presence of fibrillar insulin (InsF1)

\begin{tabular}{|c|c|c|}
\hline Donor & $Q_{d}$ & Standard \\
\hline ThT & 0.011 & ThT in buffer $\left(\mathrm{Q}_{\mathrm{s}}=10^{-4}\right)[23]$ \\
\hline ABM & 0.10 & DSP-6 in ethanol $\left(\mathrm{Q}_{\mathrm{s}}=0.05\right)[24]$ \\
\hline SQ4 & 0.039 & Nile Blue in water $\left(\mathrm{Q}_{\mathrm{s}}=0.01\right)[25]$ \\
\hline
\end{tabular}

In turn, both $\mathrm{pH} 7.4$ and $0.15 \mathrm{M} \mathrm{NaCl}$ reduce electrostatic repulsion, enabling amorphous aggregates formation, and, furthermore, it is the insulin dimer, which most likely forms amyloid nuclei in this case [26, 28]. Notably, addition of $\mathrm{NaCl}$ resulted in decrease in the lag time of insulin growth at $\mathrm{pH} 1.6$ [26]. Next, 15-times greater lag time and 12-fold slower insulin fibril growth rate were observed in $0.1 \mathrm{M} \mathrm{NaCl}$ at $\mathrm{pH} 7.4$, as compared to the corresponding values at $\mathrm{pH}$ 1.6, $0.1 \mathrm{M} \mathrm{NaCl}$ [26]. Furthermore, insulin amyloid aggregates were not formed at $\mathrm{pH} 7.4$ without stirring, suggesting a slower nucleation than at pH 1.6 (presumably due to slow structural transformations of the insulin dimer).

Table 2

FRET efficiencies in the system containing ThT, ABM, SQ4, SQ1, fibrillar (InsF1/InsF2) or control (InsN1) insulin at the maximum acceptor concentration

\begin{tabular}{|c|c|c|c|}
\hline Donor-acceptor pair & $E_{\text {Ins } F 1}, \%$ & $E_{\text {Ins } N}, \%$ & $E_{\text {Ins } F 2, \%}$ \\
\hline ThT-ABM & 86 & 12 & 94 \\
\hline ABM-SQ4 & 48 & 25 & 34 \\
\hline SQ4-SQ1 & 66 & 4 & 32 \\
\hline
\end{tabular}

It should also be emphasized that ThT affinity for insulin amyloid fibrils formed at $\mathrm{pH} 1.6$ was about 2-3 times smaller than for the protein aggregates prepared at $\mathrm{pH} 7.5$, although the binding stoichiometry in both cases was reported to be $\sim 0.1$ [29]. This fact may result in about 4-fold greater fluorescence increase of ThT in the presence of InsF2, as compared to that in InsF1 (591 and 142 for InsF2 and InsF1, respectively), and, as a consequence, to different FRET efficiencies (Table 2). Interestingly, a very high FRET efficiency was recorded in InsF2 for the ThT-ABM pair, although its value for the pair SQ4-SQ1 was close to that for the control unfibrillized insulin, suggesting low affinity of SQ1 for insulin fibrils prepared at $\mathrm{pH}$ 7.4. The observed effect can be explained by the low accessibility of the InsF2 binding sites for SQ1 whose molecule is the longest among the four employed chromophores (SQ1 length is $\sim 2.1 \mathrm{~nm}$ [19]). Thus, the InsF1 and InsF2 species can be clearly distinguished using msFRET within the above fourchromophore cascade, specifically, through estimating the FRET efficiency for the SQ4-SQ1 donor-acceptor pair. Furthermore, two types of binding sites were observed for ThT in the insulin fibrils formed at pH 7.4 [29], presumably accounting for a slightly greater FRET efficiency for the ThT-ABM pair in InsF2 as compared to that for InsF1 (Table 2). The above considerations indicate that the examined four-chromophore system can be employed not only for insulin amyloid detection, but also for distinguishing between different amyloid fibril morphologies.

The overlap integral values $(J)$ derived by numerical integration, the Förster radii and the donor-acceptor distances (calculated using the FRET efficiency values at the maximum acceptor concentration, $0.8 \mu \mathrm{M}, 0.4 \mu \mathrm{M}$ and $1.2 \mu \mathrm{M}$ for $\mathrm{ABM}, \mathrm{SQ} 4$ and SQ1, respectively) are presented in Table 3.

Table 3

FRET parameters obtained under assumption of isotropic rotation of the fluorophores in the presence of InsF1

\begin{tabular}{|c|c|c|c|}
\hline System & $J, \mathrm{M}^{-1} \mathrm{~cm}^{-1} \mathrm{~nm}^{4}$ & $R_{0}, \mathrm{~nm}$ & $r, \mathrm{~nm}$ \\
\hline ThT-ABM & $2.12 \cdot 10^{14}$ & 1.8 & 1.3 \\
\hline ABM-SQ4 & $1.27 \cdot 10^{16}$ & 5.2 & 5.3 \\
\hline SQ4-SQ1 & $1.20 \cdot 10^{16}$ & 4.4 & 3.9 \\
\hline
\end{tabular}

The pairs ABM-SQ4 and SQ4-SQ1 showed the greatest $J$ values due to small shifts $(\sim 22 \mathrm{~nm}$ and $\sim 14 \mathrm{~nm}$, respectively) between $\mathrm{ABM}(\mathrm{SQ} 4)$ fluorescence and SQ4(SQ1) absorption maxima, and high extinction coefficients of SQ4(SQ1). The largest value of the Förster radius (Table 3) was obtained for the pair ABM-SQ4 due to the greatest value of SQ4 extinction coefficient. The recovered distances are suggestive of the different binding sites for the chromophores within fibril structure, although due to their high specificity to the fibrillar assemblies, the dyes are most likely to localize in the surface grooves of the $\beta$-sheets running along the main fibril axis. Furthermore, the ABM and DMC seem to reside in the different fibril grooves due to two-fold lower ThT-ABM distance (Table 3), as compared to that for the pair ThT-DMC $(\sim 2.4 \mathrm{~nm})$ [19]. As a consequence, ABM is localized further from SQ4, while the $r$ value for the DMC-SQ4 pair was $4.5 \mathrm{~nm}$ [19]. Notably, similar distances between SQ4 and SQ1 were obtained in the two studies, 
providing additional evidence for the similar morphology of insulin amyloid fibrils prepared under acidic $\mathrm{pH}$ and elevated temperature [19].

\section{CONCLUSIONS}

In summary, cascade FRET within the four-chromophore system containing benzothiazole dye Thioflavin T (primary donor, excited at $440 \mathrm{~nm}$ ), benzanthrone dye ABM (main mediator), and the two novel squaraine dyes SQ4 and SQ1 (terminal acceptor possessing the emission maximum at $680 \mathrm{~nm}$ ), was shown to be suitable for detection and characterization of insulin amyloid fibrils prepared at $\mathrm{pH} 2$ (InsF1) or at $\mathrm{pH} 7.4,0.15 \mathrm{M} \mathrm{NaCl}$ (InsF2). The examined energy transfer cascade produced a greater enhancement of SQ1 fluorescence in the presence of InsF1 compared to that containing DMC instead of ABM [19]. Furthermore, ABM appeared to be the main mediator in a whole msFRET process (occurring in the presence of InsF1/InsF2) due to the highest FRET efficiencies (86\%/94\%) observed for the donor-acceptor pair ThT-ABM. Notably, a negligible msFRET occurred in the presence of control nonfibrillized insulin, suggesting a high specificity of the chromophores to the fibrillar structures. Both, different enhancements of the terminal donor fluorescence and distinct FRET efficiencies in the chain $\mathrm{ThT} \rightarrow \mathrm{ABM} \rightarrow \mathrm{SQ} 4 \rightarrow \mathrm{SQ} 1$ reflect different morphology of the fibrillar species InsF1 and InsF2, suggesting the applicability of msFRET for distinguishing between the various types of insulin aggregates. For instance, about 6 -fold greater increase in ThT emission in the presence of InsF2, as compared to that of InsF1, can be due to: i) the greater affinity of ThT for InsF2, and ii) the higher rigidity of InsF2 binding sites for the dye. The estimated donor-acceptor distances for the pairs ThT-ABM, ABM-SQ4 and SQ4SQ1 in the presence of InsF1, assuming the isotropic rotation of the fluorophores, fall in range $1.3 \mathrm{~nm}-5.3 \mathrm{~nm}$, suggesting that the dyes occupy different sites on the amyloid surface, most likely represented by the $\beta$-sheet grooves running parallel to the main fibril axis. The obtained results can be useful for the development of sensitive fluorescence techniques for amyloid fibril detection in vivo, based on the cascade FRET within the systems containing classical amyloid marker Thioflavin T, a near-infrared fluorescent dye and effective enhancers of its fluorescence.

\section{ACKNOWLEDGMENTS}

This work was supported by the Ministry of Education and Science of Ukraine (the Young Scientist projects № 0117 U004966 "Nano- and microsized liophylic and liophylized self-associated systems: application in modern technologies and biomedicine" and the project № 0119U002525 "Development of novel ultrasonic and fluorescence techniques for medical micro- and macrodiagnostics"). We are grateful to Dr. S. Petrushenko, V. N. Karazin Kharkiv National University, for performing the TEM measurements.

\section{ORCID IDs}

(D) Uliana Tarabara https://orcid.org/0000-0002-7677-0779, (DKateryna Vus https://orcid.org/0000-0003-4738-4016, (D)Elena Kirilova https://orcid.org/0000-0002-9577-5612, (DOlga Zhytniakivska https://orcid.org/0000-0001-9554-0090, DValeriya Trusova https://orcid.org/0000-0002-7087-071X, DGalyna Gorbenko https://orcid.org/0000-0002-0954-5053

\section{REFERENCES}

[1] J.R. Lakowicz, Principles of fluorescent spectroscopy (Plenum, New York, 1999).

[2] P.R. Selvin, Nature Struct. Biol. 7, 730-734 (2000), https://doi.org/10.1038/78948.

[3] P. Wu and L. Brand, Anal. Biochem. 218, 1-13 (1994), https://doi.org/10.1006/abio.1994.1134.

[4] L.M. Loura and M. Prieto, Front. Physiol. 2, 82 (2011), https://doi.org/10.3389/fphys.2011.00082.

[5] Y. Domanov, G.P. Gorbenko, Biophys. Chem. 99, 143-154 (2002), https://doi.org/10.1016/S0301-4622(02)00143-6.

[6] S. Buckhout-White, C. Spillmann, W.R. Algar, A. Khachatrian, J.S. Melinger, E.R. Goldman, et al. Nat. Commun. 5, 5615 (2014), https://doi.org/10.1038/ncomms6615.

[7] J. Hu, M. Liu, C. Zhang, ASC Nano. 13, 7191-7201 (2019), https://doi.org/10.1021/acsnano.9b02679.

[8] X. Hu, Y. Li, T. Liu, G. Zhang and S. Liu, ACS Appl. Mater. Interfaces. 7, 15551-15560 (2015), https://doi.org/10.1021/acsami.5b04025.

[9] D. Navarathne, Y. Ner, J.G. Grote, G.A. Sotzing, Chem. Commun. (Camb). 47, 12125-12127 (2011), https://doi.org/10.1039/C1CC14416B.

[10] G. Ulrich, C. Goze, M. Guardigli, A. Rodda and R. Ziessel, Angew. Chem. Int. Ed. 44, $3694-3698$ (2005), https://doi.org/10.1002/anie.200500808.

[11] X. Duan, S. Wang and Z. Li, Chem. Commun. 2008, 1302-1304 (2008), https://doi.org/10.1039/B717300H.

[12] A. Aneja, N. Mathur, P.K. Bhatnagar and P.C. Mathur, J. Biol. Phys. 34, 487-493 (2008), https://doi.org/10.1007/s108670089107-y.

[13] V. Raicu, J. Biol. Phys. 33, 109-127 (2007), https://doi.org/10.1007/s10867-007-9046-z.

[14] L. He, X. Wu, J. Simone, D. Hewgill and P.E. Lipski, Nucleic Acid Res. 33, 61-73 (2005), https://doi.org/10.1093/nar/gni057.

[15] E. Galperin, V. V. Verkhusha and A. Sorkin, Nature Methods, 1, 209-217 (2004), https://doi.org/10.1038/nmeth720.

[16] P. Tinnefeld, M. Heilemann and M. Sauer, Chem. Phys. Chem 6, 217-222 (2005), https://doi.org/10.1002/cphc.200400513.

[17] B. Albinsson, J.K. Hannestad and K. Borjesson, Coordination Chemistry Reviews, 256, 2399-2413 (2012), https://doi.org/10.1016/j.ccr.2012.02.024.

[18] G. Gorbenko, V. Trusova, T. Deligeorgiev, N. Gadjev, C. Mizuguchi and H. Saito, J. Mol. Liq. 294, 111675 (2019), https://doi.org/10.1016/j.molliq.2019.111675.

[19] U. Tarabara, M. Shchuka, K. Vus, O. Zhytniakivska, V. Trusova, G. Gorbenko, N. Gadjev and T. Deligeorgiev, East European Journal of Physics, 4, 58-69 (2019), https://doi.org/10.26565/2312-4334-2019-4-06. 
[20] L.M. Loura and M. Prieto, Front. Physiol. 2, 82 (2011), https://doi.org/10.3389/fphys.2011.00082.

[21] O. Zhytniakivska, V. Trusova, G. Gorbenko, E. Kirilova, G. Kirilov and P. Kinnunen, Вісник Львівського університету. Серія біологічна. 68, 279-285 (2014), http://nbuv.gov.ua/UJRN/VLNU_biol_2014_68_30.

[22] M. Groenning, J. Chem. Biol. 3, 1-18 (2010), https://doi.org/10.1007/s12154-009-0027-5.

[23] A.I. Sulatskaya, A.A. Maskevich, I.M. Kuznetsova, V.N. Uversky and K.K. Turoverov, PLoS ONE, 5, e15385 (2010), https://doi.org/10.1371/journal.pone.0015385.

[24] J.A. Vladimirov and G.E. Dobretsov, Флуоресиентные зонды в исследовании биологических мембран [Fluоrescent probes in study of biological membranes], (Nauka, Moscow, 1980), pp. 40. (in Russian)

[25] H.P. Oliveira, A.J. Camargo, L.G. Macedo, M.H. Gehlen and A.B. da Silva, Spectrochim. Acta A Mol. Biomol. Spectrosc. 58, 3103-3111 (2002), https://doi.org/10.1016/S1386-1425(02)00119-1.

[26] L. Nielsen, R. Khurana, A. Coats, S. Frokjaer, J. Brange, S. Vyas, V.N. Uversky and A.L. Fink, Biochemistry, 40, 6036-6046 (2001), https://doi.org/10.1021/bi002555c.

[27] J.L. Jiménez, E.J. Nettleton, M. Bouchard, C.V. Robinson, C.M. Dobson and H. Saibil, Proc. Natl. Acad. Sci. USA, 99, $9196-$ 9201 (2002), https://doi.org/10.1073/pnas.142459399.

[28] H. Yoshihara, J. Saito, A. Tanabe, T. Amada, T. Asakura, K. Kitagawa and S. Asada, J. Pharm. Sci. 105, 1419-1426 (2016), https://doi.org/10.1016/j.xphs.2016.01.025.

[29] M. Groenning, M. Norrman, J.M. Flink, M. van de Weert, J.T. Bukrinsky, G. Schluckebier and S. Frokjaer, J. Struct Biol. 159, 483-497 (2007), 10.1016/j.jsb.2007.06.004.

\section{КАСКАДНИЙ ПЕРЕНОС ЕНЕРГІЇ В АМІЛОЇДНИХ ФІБРИЛАХ ІНСУЛІНУ, ДОПОВАНИХ ТІОФЛАВІНОМ Т, БЕНЗАНТРОНОВИМ ТА СКВАРАЇНОВИМИ БАРВНИКАМИ}

У. Тарабара $a^{a}$, К. Вус ${ }^{a}$, М. Щука ${ }^{a}$, О. Кірілова ${ }^{b}$, Г. Кірілов ${ }^{b}$, О. Житняківська ${ }^{a}$, В. Трусова ${ }^{a}$,

Г. Горбенко ${ }^{\mathrm{a}}$, Т. Делігеоргісв ${ }^{\mathrm{c}}$

а Кафедра медичної фізики та біомедичних нанотехнологій,

Харківський національний університет імені В.Н. Каразіна

м. Свободи 4, Харків, 61022, Україна

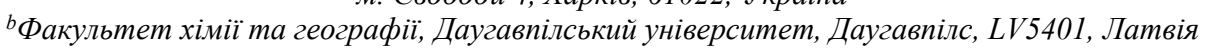

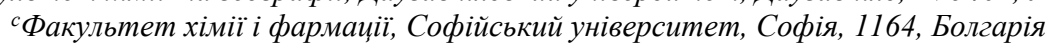

Протестовано можливість використання трьохетапного індуктивно-резонансного переносу енергії (IPПЕ) у системі зондів, що включала класичний амілоїдний маркер тіофлавін T (ThT), бензантроновий медіатор ABM та сквараїнові барвники SQ1, SQ4, для детектування та характеризації амілоїдних фібрил інсуліну. Виявлено високі значення ефективності багатоетапного IPПЕ у даному ансамблі хромофорів за наявності амілоїдних фібрил інсуліну, сформованих при підвищених температурах та $\mathrm{pH} 2$ (InsF1) або $\mathrm{pH} 7.4,0.15 \mathrm{M} \mathrm{NaCl}$ (InsF2), у той час як незначний IPПЕ спостерігали у нефібрилізованому білку (контроль), що свідчить про специфічність зондів каскаду до крос- $\beta$-складчатої архітектури амілоїдних фібрил. Зокрема, ефективність IPПЕ для донорно-акцепторних пар ThT-ABM, ABM-SQ4 та SQ4-SQ1 за максимальної концентрації акцептора $(\sim 0.4 \mu \mathrm{M}-1.6 \mu \mathrm{M})$ становила 86\%/94\%, 48\%/34\% та 66\%/8\%, відповідно, у присутності InsF1/InsF2. Найбільш суттєві відмінності між InsF1/InsF2 та контрольним білком виявлено для донорноакцепторної пари ThT-ABM, що свідчить про ключову роль АВМ як медіатора у процесі багатоетапного IPПЕ. При оцінці відстаней між донором і акцептором у фібрилярних агрегатах InsF1, за умови ізотропного обертання зондів отримані значення 1.3 нм, 5.3 нм та 3.9 нм для пар ThT-ABM, ABM-SQ4 та SQ4-SQ1, відповідно. Ці результати свідчать про різні сайти зв'язування фібрил для зондів каскаду, хоча завдяки їх високій специфічності до фібрилярних структур, барвники мають бути локалізовані у поверхневих жолобках $\beta$-листів, що простягаються уздовж головної осі амілоїдної фібрили. Слід зауважити, що різниця у морфології амілоїдних фібрил може бути чітко охарактеризована за допомогою багатоетапного IPПЕ. Зокрема, за даними електронної мікроскопії виявлено, що фібрили InsF2 були більш тонкими, короткими та містили аморфні агрегати, у порівнянні з InsF1. Вочевидь, різні шляхи формування амілоїдних фібрил при нейтральному та кислому значеннях $\mathrm{pH}$, призвели до різної афінності зондів до сайтів зв'язування фібрил, та, як наслідок, до різних значень ефективності IPПЕ, особливо для пари SQ4-SQ1. Здатність ThT слугувати ефективним підсилювачем для SQ4 та SQ1, що флуоресціюють у ближній інфрачервоній області, при використанні бензантронового флуорофору АВМ у якості медіатора дозволяє детектувати фібрили інсуліну в оптичному вікні біологічних зразків завдяки стоксовому зсуву чотирьоххромофорної системи близько 240 нм. Запропонований підхід, що базується на багатоетапному IPПЕ, можна використовувати не лише для детектування амілоїдних фібрил інсуліну, але і для диференціювання морфології фібрилярних агрегатів та встановлення механізмів розвитку ін'єкційно-локалізованого інсулінового амілоїдозу.

КЛЮЧОВІ СЛОВА: АБМ, каскадний індуктовно-резонансний перенос енергії, амілоїдні фібрили інсуліну, квантовий вихід, тіофлавін Т.

\section{КАСКАДНЫЙ ПЕРЕНОС ЭНЕРГИИ В АМИЛОИДНЫХ ФИБРИЛЛАХ ИНСУЛИНА, ДОПИРОВАННЫХ ТИОФЛАВИНОМ Т, БЕНЗАНТРОНОВЫМ И СКВАРАИНОВЫМИ КРАСИТЕЛЯМИ У. Тарабара ${ }^{a}$, К. Вус ${ }^{\mathrm{a}}$, М. Щука ${ }^{\mathrm{a}}$, Е. Кирилова ${ }^{\mathrm{b}}$, Г. Кирилов ${ }^{\mathrm{b}}$, О. Житняковская ${ }^{\mathrm{a}}$, В. Трусова $^{\mathrm{a}}$, Г. Горбенко ${ }^{\mathrm{a}}$, Т. Делигеоргиев \\ ${ }^{a}$ Кафедра медииинской физики и биомедицинских нанотехнологий, Харьковский начиональный университет имени В.Н. Каразина пл. Свободы 4, Харьков, 61022, Украина \\ ${ }^{b}$ Факультет химии и географии, Даугавпилский университет, Даугавпилс, LV5401, Латвия ${ }^{c}$ Факультет химии и фармачии, Софийский университет, София, 1164, Болгария}

Протестировано возможность применения трехэтапного индуктивно-резонансного переноса энергии (ИРПЭ) в системе зондов, которая включала классический амилоидный маркер тиофлавин Т (ThT), бензантроновый медиатор АВМ и сквараиновые красители SQ1, SQ4, для детектирования и характеризации амилоидных фибрилл инсулина. Обнаружено 
высокие значения эффективности многоэтапного ИРПЭ в данном ансамбле хромофоров в присутствии амилоидных фибрилл инсулина, сформированных при повышенных температурах и $\mathrm{pH} 2$ (InsF1) или pH 7.4, $0.15 \mathrm{M} \mathrm{NaCl}$ (InsF2), в то время как незначительный ИРПЭ наблюдали в нефибриллизированном белке (контроль), что свидетельствует о специфичности зондов каскада к $\beta$-складчатой архитектуре амилоидных фибрилл. В частности, эффективность ИРПЭ для донорно-акцепторных пар ThT-ABM, ABM-SQ4 и SQ4-SQ1 при максимальной концентрации акцептора $(\sim 0.4 \mu \mathrm{M}-1.6 \mu \mathrm{M})$ составила $86 \% / 94 \%, 48 \% / 34 \%$ и 66\%/8\%, соответственно, в присутствии InsF1/InsF2. Наиболее существенные отличия между InsF1/InsF2 и контрольным белком обнаружены для донорно-акцепторной пары ThT-ABM, что свидетельствует о ключевой роли АВМ как медиатора в процессе многоэтапного ИРПЭ. При оценке расстояний между донором и акцептором в фибриллярных агрегатах InsF1, при условии изотропного вращения зондов получены значения 1.3 нм, 5.3 нм и 3.9 нм для пар ThT-ABM, ABM-SQ4 и SQ4-SQ1, соответственно. Эти результаты свидетельствуют о разных сайтах связывания фибрилл для зондов каскада, хотя благодаря их высокой специфичности к фибриллярным структурам, красители должны локализоваться в поверхностных желобках $\beta$-листов, которые простираются вдоль основной оси амилоидной фибриллы. Следует отметить, что различия в морфологии амилоидных фибрилл можно четко охарактеризовать при помощи многоэтапного ИРПЭ. В частности, согласно данным электронной микроскопии, фибриллы InsF2 были более тонкими, короткими и содержали аморфные агрегаты, в отличие от InsF1. Очевидно, разные пути формирования амилоидных агрегатов при нейтральном и кислом значениях $\mathrm{pH}$, обусловливают разную афинность зондов к сайтам связывания фибрилл, и, следовательно, разные значения эффективности многоэтапного ИРПЭ, особенно для пары SQ4-SQ1. Способность ThT служить эффективным усилителем для SQ4 и SQ1, которые флуоресцируют в ближней инфракрасной области, при использовании бензантронового флуорофора АВМ в качестве медиатора, позволяет детектировать амилоидные агрегаты инсулина в оптическом окне биологических образцов благодаря стоксовому сдвигу четыреххромофорной системы около 240 нм. Предложенный поход, который базируется на многоэтапном ИРПЭ, можно использовать не только для детектирования амилоидных фибрилл инсулина, но и для дифференцирования морфологии фибриллярных агрегатов и выяснения механизмов развития инъекционно-локализированного инсулинового амилоидоза.

КЛЮЧЕВЫЕ СЛОВА: АБМ, каскадный индуктивно-резонансный перенос энергии, амилоидные фибриллы инсулина, квантовый выход, тиофлавин Т. 